\title{
Problems and Solutions of Wind Power Industry in China
}

\author{
Huang Mai $^{1}$ \\ ${ }^{1}$ Practical 1301, North China Electric Power University, Beijing, China, 102206
}

Keywords: Wind Power, Industrial Policy, Installed Capacity

\begin{abstract}
As an environment friendly energy source, the wind power has been widely explored and used all over the world. The wind power industry in China is developing rapidly in recent years. However, due to the low basis of the industry and the deficiency of industrial policy, some problems existing in the wind power industry hinders the further development of the industry, such as excessive price of wind power, blind construction of industrial project, sever problem of wind abandon and false data of installed capacity. This paper analyses these problems and gives the corresponding countermeasures in order to promote the healthy development of the wind power industry.
\end{abstract}

\section{Current Situation of Wind Power Industry in China}

Chinese economy has maintained the medium to high speed growth during the "13th Five-Year" period. This ensures that the wind power industry continues to maintain a rapid pace of development. At the same time, the economic structure is more optimized and the power use is more effective. Under the new normal, the development mode will change from the scale speed to the quality benefit type. The new normal economy plays an important role in the integration of industrial economy. The wind power industry's excessive capacity is slowly decreasing in the macroeconomic environment. The wind power companies have returned to the normal track.Wind power companies focus on the technology research and development and innovation in the competition to optimize the industrial structure.Only the steady growth can maintain the entire wind power industry long-term sustainable development.

As the pioneer of the economy of low-carbon and emission reduction, the pollutant emission of the wind power industry is zero. It has high social recognition and relatively mature technology. In recent years, the state adopted a number of control measures to solve the problem of wind power consumption.The power grid construction also entered the accelerated phase. China's new wind power installed machine market substantially booststhe growth of the global wind power industry. The installedwind powercapacity ofChinafrom2010 to2015 is showed in Table 1.

Table 1 Installedwind powercapacity ofChinafrom 2010 to2015

\begin{tabular}{|c|c|c|c|c|c|}
\hline Year & 2011 & 2012 & 2013 & 2014 & 2015 \\
\hline cumulative installed capacity & 62.4 & 73.5 & 91.4 & 114.6 & 129.0 \\
\hline incremental installed capacity & 17.6 & 13.0 & 16.1 & 23.2 & 32.9 \\
\hline
\end{tabular}

\section{Problems of Wind Power Industry in China}

The National Development and Reform Commissiondivided the wind energy resource area into four categories and developed a corresponding wind power benchmark price in July 2009to promote the healthy development of wind power market norms. With the wind power equipment price and the 
project development costs decreased significantly, National Development and Reform Commission began brewing wind electricity price reduction plan, and heldwind power prices informal discussion in September 2014. It informed the price adjustment scenario. Electricity pricing policy is one of the most important policies to support the development of China's wind power industry. It provides a stable and attractive wind power price for the sustainable development of wind power industry.Generally speaking, the wind power price should be developed on the basis of project costs and a reasonable profit, considering wind power resources, project construction time and grid consumptive factors. According to the above factors, the wind powerprice in China is excessively high, needing further decrease.

The wind power industry boosted suddenly when the National Renewable Energy Law was issued in 2005. It showed a beautiful picture for the wind power companies. Many wind power companiesscrambled for the favorable profit. They bought the wind power equipment, employed the professional talents and applied for the wind power projects. Many domestic wind power grids have a distance of hundreds of kilometers distance pipeline construction costs. The high transmission cost and low electricity grid national price were uninteresting to the big companies. Based on the relevant laws, local governments made many regulations to stimulate the companies to take part in the wind power industry. The wind power investors competed fiercely to achieve the wind power privilege. With the issuedprogram, the competition spread from the wind power projects to the field of equipment and talent. The phenomenon of China's overheatingwind power industry is very serious. The blind construction of wind power industry will lead to the unhealthy development of the competitors.

The wind abandon phenomenon firstly occurred in 2010. Then with the rapid diffusion, wind abandon has become the industry's illness. The illness was very serious in 2012. The abandoned wind power in China soared to 20.8 billion kilowatts, almost two times in 2011. The reasons for abandoning the wind power are complex. The fundamental reason is the competitive interest of every energy institution. Excessive administrative planning and scheduling led to the market leverage failure. First of all, the planning of China's power supply is lack of overall planning. The system operation and management efficiency is not high, either. There is a benefit game between thermal power and new energy sources. As the wind scale is expanding day by day and the economy entered a new norm, the excessive thermal power installed capacity is becoming more and more serious. The game of installed capacity has become increasingly fierce.Secondly, compared with the conventional energy sources, wind power price is higher than others. The power grid enterprises acquisition cost of wind poweris higher than thermal power. At the same time, wind power needs the peak shaving services of other power. However, the ancillary services have not yet market-oriented. It's another influence of wind abandon.

The rapid development of the wind power industry created a rapid growth of wind power installed capacity. But whenthe wind power project is completed, there is a situation that the actual wind power cannot keep upwith the installed capacity. The false installed capacity can do great harm to the industry. For example, it can lead to the idle of wind power equipment, resulting in a waste of resources. This is a direct result of wind field in the pre-construction costs increased, and in later generation shortage means wind field construction cost recovery period to some extent, which leads to the reduction of the efficiency of investment. In addition, the construction of wind power projects is supported by the bank's loan. The wind power generation shortage will also bring difficulties of the loan payment. 


\section{Countermeasures of Wind Power Industry in China}

The electricity sales revenueis the main business income of the wind power company. It is directly related to the sale of electricity and electricity prices and the main business level is directly related to the level of income.According to the China's acquisition policy, the morethe average annual investment operation of installed capacityis, the more the sales revenue is. And the profit of the wind power company is also higher. We should furtherclarify the internet price subsidy execution time. That is to say, we should clarify the years of the execution after power plant puts into operation to stimulate the enthusiasm of investors. We should deepen and refine the different regional pricing mechanism to adjust measures to local conditions for the development of regional development. We also suggest the wind power price mechanism of fixed costs and variable costs of wind power. When technical progress reduces the cost of wind power generation, policy formulation or relevant departments can adjust related parameters to reduce wind power price. When the changesof macroeconomic environment lead to the increase of the cost of wind power project, the policy makers can raise the price to protect the enthusiasm of the wind power companies.

China can improve the previous "renewable energy law" to avoid some enterprises blinding competitionin the project bidding. It is suggested that the set of legal systeminclude a reasonable price mechanism of bidding related policiesfor a larger scale or a smaller scale wind power project. In order to encourage the enthusiasm of enterprises in the real production and the quality of the product of wind power, legal system shall also contain the implementation of these enterprises preferential tax of the specific policy. Also wind power project in charge of government departments to strengthen supervision of successful enterprise production and operation of, and regularly check the actual situation of the enterprise, the unreasonable and illegal production enterprise or business to timely stop, protect the local people with electrical safety and power quality. We encourage the wind power companies to safeguard their rights. Firstly, it can promote the implementation of laws and regulations. Secondly, it can remind the local government and the power grid corporation administrations strictly conform to the laws and prevent violations of the law and breaches of disciplines. Thirdly, it can improve the enterprise's legal consciousness and legal awareness.

The wind power consumptive job is an important guarantee for the healthy development of China's wind power industry. It is also an important measure of China's clean construction of low carbon, safe and efficient modern energy system. We suggest the international cooperation and national finance investment to set up the wind resource assessment center which conforms to the international standards to provide resources survey and detailed survey of technical support for the state and enterprises. On the one hand, we should do a good job of the national wind energy resource survey and reconnaissancefor large-scale development of wind power. It can give priority to the development of wind energy resources, strengthen the wind energy resource assessment and planning and establish a plenty of wind power project reserves. On the other hand, we should construct the power grid well to achieve the orderly development of wind power resources.Wind energy resources are very rich in the north, northwest, and northeast of China. But the distance from the load center is far away and the power grid structure is relatively weak, which restricts the development and utilization of wind energy resources. We formulate the scientific program of unified planning and intensive development to improve the return on investment of wind power developers and reduce the cost of the access to the power grid system, whichis conducive to the healthy development of wind power industry. 
The actual production of the wind power enterprise is far away from the installed capacity in the internet. The government should control and regulate the installed capacity in the internet and the actual installed capacity. First of all, government officials should be self-disciplined. The self-disciplinedofficials not only see the reported capacity due to the selfishness, but also pay attention to the enterprise actual grid electricity.Secondly, the preferential policies formulated by the government should refine the grid electricity preferential policies.In addition, the government should pay more attention to the installed capacity in the internet in the process of supervision. The government should timely guide the enterprises of low power consumption in the internet to improve internet consumption.

\section{Conclusion}

As the most promising renewable energy generation technology, wind power generation technologyhas received more and more attention all over the world. China has rich wind energy resources and practical experience. After fully solving the problems existing in the industrial development, the wind power industry will make a great contribution to the adjustment of China's environmental protection industry and energy structure.

\section{References}

[1] Zhang Caiqing, Li Qi, Research on Technological Innovation Ability Evaluation Index System of China s Wind Power Industry, J., Scientific Management Research, 2013, 31(6): 57-59.

[2] LiXiulei, Comparative Study on the Domestic and International Policy of Wind Power Industry, J., Energy and Energy Conservation, 2014(12): 87-88+91.

[3] LinXianghong, GaoJian, Liu Bin, WeiYouzhou, Study on Current Situation of Global Offshore Wind Power Industry andthe Enlightenments for China, J., Ecological Economy, 2014,30(10): 82-86.

[4] Wang Changlu, Wang Weigong, Zhang Liyong, QiaoXuetao, TheAnalysis of ChinaWind Power Industry, J., JournalofChongqingUniversity, 2015,38(1): 148-152.

[5] ZhuYuchen, The Thinking about the Development ofWind Power Industry in China, Journal of Anhui Electrical Engineering Professional Technique College, 2009, 14(3): 74-76. 